\title{
SUMMER FLOCKS OF THE WILLOW PTARMIGAN IN THE NORTH OF THE YAMAL PENINSULA
}

\author{
VLADIMIR V. TARASOV \\ Institute of Plant and Animal Ecology, RAS, Ural Branch, Ekaterinburg, Russia \\ E-mail: grouse@bk.ru
}

\begin{abstract}
Numerous flocks of up to 100 Willow Ptarmigan (Lagopus lagopus) were observed in 1989, 1992 and 1994 during the nesting season. In these years, there were large numbers of lemming predators at the depression of the lemming cycle. Individual marking showed that ptarmigan pairs that lost their clutches joined groups of unmated males. In 1989, numerous Snowy Owls (Bubo scandiacus) drove the ptarmigan into flood-plain willow thickets where they formed flocks even containing males from nearby $(<2 \mathrm{~km})$ territories with incubating or brooding females. There were few Snowy Owls in 1992 and 1994, but abundant Arctic Foxes (Alopex lagopus) ruined ptarmigan nests; in those years, flocks were noted both on flood-plains and uplands. A true population reserve, meaning individuals capable of reproduction but unable to obtain a territory at highest density, were not observed in all years of observation. In the north of the Yamal Peninsula, the Willow Ptarmigan spends the main part of the year within flocks because of the very long winter and very short summer. We suspect that, at the northern limit of distribution, a rapid return to flocking is adaptive when an obstacle to reproduction arises. Received 31 December 2010, accepted 25 April 2011.
\end{abstract}

Tarasov, V. V. 2011. Summer flocks of the Willow Ptarmigan in the north of the Yamal Peninsula. Pages 197-204 in R. T. Watson, T. J. Cade, M. Fuller, G. Hunt, and E. Potapov (Eds.). Gyrfalcons and Ptarmigan in a Changing World, Volume II. The Peregrine Fund, Boise, Idaho, USA. http://dx.doi.org/10.4080/gpcw.2011.0219

Key words: Willow Ptarmigan, Lagopus lagopus, summer flocks, nesting season, population reserve, Yamal.

SURPLUS OF REPRODUCTIVELY CAPABLE individuals in bird populations is the rather usual phenomenon (Patterson 1980). At achievement of high population density, surplus individuals lose the option of occupying a territory, and in this case, they form a population reserve. Presence of such a reserve can be revealed experimentally by removing breeding individuals and observing their replacement by others.
There have been many population studies of Willow Ptarmigan (Lagopus lagopus), an important game-bird species. Data on the presence of surplus males of this species, not capable of occupying a territory, are available from interior Alaska (Moss 1972) and from removal experiments in Canada that demonstrated the presence of a reserve of both males and females (Hannon 1983, 1984, Hannon and 
Rowland 1984). Marked individuals make it easy to identify birds that reappear on an experimental site. However, sometimes such experiments are carried out without individual marking, or a conclusion about a population reserve is based on indirect observation that nonterritorial birds are gathered in flocks. As a rule, there is mention of fierce fighting, and that all areas of tundra have been divided between territorial males. The flocks of ptarmigan occurring in the tundra during nesting time have consisted mainly of males, and the idea that they were waiting for the opportunity to obtain a suitable nesting territory looked quite plausible (Mikheev 1948, Höhn 1967, Voronin 1978, 1979, Bergerud et al. 1985).

Ryabitsev (1989) has shown that without individual marking, it is impossible to draw conclusions on presence or absence of the population reserve. In 1986, in the Central Yamal, he observed flocks of 3-20 individuals, and sometimes more than 50 male Willow Ptarmigan. It appeared that these flocks had been formed by unmated males which previously had territories, but had left them after they could not form a pair because of a distorted sex ratio. In the first year of work with marked ptarmigan in the Northern Yamal (1989), we (Ryabitsev and Tarasov 1994) also observed numerous flocks during nesting time. This occurred in conditions of high predator numbers at the depression in the number of rodents; predators not only ruined nests, but also attacked adult ptarmigan. That year, the flocks were originally formed by unmated males, but later many birds that lost nests (both males, and females) joined the flocks, as well as mated males whose females hatched clutches. Subsequently, in the summer of 1992 and 1994, we again observed large flocks of Willow Ptarmigan in the Northern Yamal. In the present article, we generalize these observations.

\section{MeTHODS}

We conducted our study during 1989-1995 at the Yaibari Ornithological Field Station $\left(71^{\circ} 04^{\prime} \mathrm{N}, 72^{\circ} 20^{\prime} \mathrm{E}\right)$, located in the north of the Yamal Peninsula, on the southern border of the arctic tundra subzone. On a $3-\mathrm{km}^{2}$ study plot, ptarmigan were caught, banded, and individually marked. We caught aggressive, territorial males by means of an automatic snare on a stuffed male in mating plumage, an effective method that allowed us to mark almost all the males on a study plot in a few days. Unmated males, who reluctantly reacted to a stuffed male, were sometimes caught on a stuffed female. We caught females by means of a nonautomatic snare on the nests during hatching. We determined the age of captured birds on the basis of pigmentation of the first two paramount wing feathers (Bergerud et al. 1963). That allowed us to distinguish yearlings (born in previous year) from older birds.

The captured birds were banded with colored standard metal (numbered) and colored plastic bands; lost bands were not registered. We accurately read combinations of color-bands on ptarmigan by means of 12-power binoculars from a distance of 30-40 m, and even further, depending on illumination and background. As additional marking, painted wing feathers allowed us to identify birds from a distance to $300-400 \mathrm{~m}$. Wings of males were painted yellow and red, and females, blue and green. It was possible to distinguish painted ptarmigan until the end of July when wing feathers molted.

Annually, after territories formed, we experimentally removed territorial males for evaluation of the population reserve. In two cases, we were assisted by Snowy Owls (Bubo scandiacus).

\section{Results}

At the beginning of each breeding season, we mapped individual territories of males, thus determining a spring density of the population. Results varied from four to nine territorial males (pairs) per $\mathrm{km}^{2}$ in the different years, with an unweighted average nesting density of 
Table 1. Sex structure of the population of Willow Ptarmigan at the Yaibari station (plot 3-km²).

\begin{tabular}{|c|c|c|c|c|}
\hline Year & Number of females & Total & $\begin{array}{c}\text { Number of males } \\
\text { Unmated }\end{array}$ & Bigamous \\
\hline 1989 & 21 & 21 & 3 & 3 \\
\hline 1990 & 16 & 15 & 0 & 1 \\
\hline 1991 & 25 & 19 & 0 & 6 \\
\hline 1992 & 25 & 27 & 3 & 1 \\
\hline 1993 & 21 & 22 & 4 & 3 \\
\hline 1994 & 23 & 22 & 2 & 3 \\
\hline 1995 & 10 & 12 & 2 & 0 \\
\hline
\end{tabular}

$6.5(\mathrm{SE} \pm 0.6)$ males per $\mathrm{km}^{2}(\mathrm{n}=7$ years $)$. Some males remained unmated, while others had two females (Table 1). After experimental removal of territorial males, we observed no replacement by outside males and the territories were divided between neighboring males, proving the absence of a population reserve. In the Central Yamal, even at a density of 14 males per $\mathrm{km}^{2}$ during such experiments, no entry of a new male on a released territory was observed (Ryabitsev 1989).

Unmated Male Phenomenon.-The occurrence of unmated males was partly, but not completely explained by a distortion in sex ratio which slightly deviated in different years from an average value of 1:1. We encountered unmated males in all years of our research, except in 1990 and 1991 (Table 1). The percent of unmated males we observed in the Northern Yamal (about 10\% on the average) should be regarded as rather low. Ryabitsev (1989) in Central Yamal noted up to $30 \%$ unmated males. During a peak of ptarmigan numbers on the Bolshezemel'skaya tundra, Voronin $(1978,1979)$ observed that $40 \%$ of males were unmated, though he considered them surplus birds.

The total number of female ptarmigan after winter in the tundra often happens to be below the number of males because of greater winter mortality among females. The latter depart ear- lier in migration and move further south than males (Weeden 1964, Potapov 1985, Piminov 1985, 1990). Distant migration and consequently higher hunting pressure distorts the sex ratio, especially at low numbers when the males winter in the tundra. Hunting therefore quite disproportionately affects females in many regions. It is nevertheless curious, that at Yaibari Station, on average, for all years of observations, the ratio of males and females was almost equal at 1:1. Absence of a distorted sex ratio suggests that females nesting in Northern Yamal, as well as males, winter in the tundra and do not reach the main hunting areas. It appears that the population of Willow Ptarmigan in the Northern Yamal is practically unaffected by hunting.

In Canada, young males have been shown to be unmated (Hannon 1983, Hannon and Barry 1986). After shooting territorial males, yearling males of unknown origin were found on those territories. In our studies, ability to form a pair did not depend on the age of the male. Of nine marked, unmated males, there were only two yearlings. The probability of remaining without a female can depend on the quality of the male's territory (Verner 1964, Verner and Willson 1966, Orians 1969, 1978). We saw unmated males in different parts of a study plot, but among 14 such males known in 1989-1995, not one acquired territory in the 
flood-plain willow tundra, the habitat most preferred by females. This seems to confirm the suggested assumption, but if such dependence really exists, the percent of unmated males should increase proportional to density. That was not observed, so territorial quality here is apparently not of great importance. Because of low nesting density in the study area, competition for nesting sites is insignificant. If one considers all habitats in the northern Yamal to be generally suboptimal in comparison with more southern areas, it is reasonable to expect an increase in percent of unmated males here, but that also contradicts the facts. Finally, as Ryabitsev (1993) has shown, the concept of suboptimum habitat is rather relative.

At initial stages of the nesting period, the territorial behavior of unmated males did not differ much from behavior of mated ones. But gradually, the territorial activity of unmated males decreased. By the middle of June, it was possible to observe, how territorial males found and expelled the hidden intruders, most likely searching for females. Unmated males flew widely over the tundra, often visiting the territories of neighbors. When captured, they reacted to a stuffed male less vigorously and, when frightened, they flew further away than mated males. About this time, unmated males began to unite in small (7-10 individuals), settled groups, or, more precisely, clubs, occasionally returning to their territories. By the beginning of July, unmated males had definitively left their territories and moved to flocks. Over the period of our studies, we observed summer clubs of unmated males in all years except 1990 and 1991, and only during these two years were no unmated males apparent among male residents (Table 1 ). In some years, summer flocks reached 100 and more individuals, and not only consisted of unmated males, but of some other males and females too. Such flocks were very conspicuous in 1989, 1992 and 1994.
Observations in 1989. - In spring 1989, there were high numbers of Siberian lemmings (Lemmus sibiricus), and also lemming predators, especially, Arctic Foxes (Alopex lagopus), Snowy Owls, and Pomarine Skuas (Stercorarius pomarinus) in the Northern Yamal. In the middle of June, already at the height of a nesting season, mass death among the lemmings led to a sharp depression of their number. Dead small animals were everywhere, and predators collected their corpses. When nests appeared, Arctic Foxes and skuas completely switched to feeding on eggs and nestlings, and the reproductive success of all bird species was low. After the mass elimination of lemmings, adult ptarmigan became the main food of Snowy Owls. In spring, the density of owls was so high that we estimated 20-30 individuals within a $25-\mathrm{km}^{2}$ study area, whereas by the end of July, their abundance fell to 10-15.

The appearance of the first small flocks of ptarmigan (to 7-10 males) at the end of June coincided with the disappearance of unmated males from the territories. Spring marking of individuals revealed that these flocks had been initially formed by those unmated males. In the beginning of July, flocks of unmated birds contained both males and the females who had lost clutches, and also males whose territories were within $1 \mathrm{~km}$ from a flock site and whose females sat on nests (Ryabitsev and Tarasov 1994). By the middle of July, almost all males had left their territories irrespective of whether the nest had been depredated. At this time, the flocks numbered up to 60-70 individuals, scattered over flood-plain willow thickets, and we observed males there whose territories were as much as $2 \mathrm{~km}$ away.

It is possible that the formation of flocks in 1989 was caused by constant attacks of Snowy Owls, the predator that puts the greatest pressure upon adult ptarmigan. Owls often chased ptarmigan, and we found evidence that such pursuits were successful. We saw a marked male being caught by an owl. In the area of four nests on a study plot with marked females 
and hatched nestlings, we later found remains of two of these females with the obvious signature of owl predation. Their broods, obviously, died, and the fate of the other two broods was unknown, but most likely, they too were lost. An additional clutch on a study plot remained without a brood hen. In the middle of July, we observed six unfledged broods, and adult males were present at only two of them. During this time, practically all marked ptarmigan disappeared from a study plot, but many of them were seen in flocks. It is known that flocking enables birds to escape from predators, and this has been clearly shown for wintering sandpipers (Page and Whitacre 1975, Stinson 1980). At the end of July and the beginning of August, we carefully surveyed about $1000 \mathrm{~km}$ and could not find a fledged brood. Our last encounter with a brood had been of two fledglings accompanied by a pair of adults on 21 July.

Observations in 1992.-The situation in 1992, which also was a year of predators, was different. Lemmings disappeared not in the beginning of summer, but at the end of winter. By the beginning of the ptarmigan nesting season, the owls had almost all migrated and did not represent such a threat to adult ptarmigan as they had in 1989. Nevertheless, there were many Arctic Foxes that intensively ruined the nests of ptarmigan, and the nesting success of the latter was extremely low (Tarasov 1997). That year we managed to find very few nests despite the help of a dog, because Arctic Foxes found them first. The majority of marked ptarmigan, following the depredation of their nests, left a study plot and united in flocks.

By the end of July 1992, the flocks reached 50-100 birds and consisted of both males and females. However, in these flocks, the birds did not escape from predators as they had in 1989 when they were hidden in flood-plain willow thickets and absent on the uplands. In 1992, the flocks were located both in floodplains and on uplands, so it was probably not a fear of predators that forced the ptarmigan to unite in flocks. Spring came very late in 1992: ducks, geese, and divers practically did not nest because of late snow-melting. Nevertheless, ptarmigan started nesting, and the mass depredation of their nests by Arctic Foxes became the principal cause of the formation of large summer flocks.

Observations in 1994.-Events in 1994 were similar to those in 1992. Lemmings' numbers were at the average level in spring, and Arctic Foxes were not abundant. However, in the beginning of summer, there was a partial reduction of lemmings, such that the remaining ones stayed in holes and became inaccessible. Some days before the hatching of the ptarmigan chicks, there appeared many vagrant Arctic Foxes in the tundra that within a few days ruined almost all the nests that were under observation (Tarasov 1997). The nest destruction, as had occurred 1992, caused many birds to join the clubs of unmated individuals. One flock settled in a ravine on a study plot, and by 8 July, it numbered 15 males. By 20 July, it contained 25 birds, including marked males and females that had lost nests. At the end of summer 1994, in flood-plain willow thickets, we also encountered tenuous groups of molting ptarmigan (up to 10-20 birds) among which we saw eight marked individuals who had earlier lost their clutches and whose territories were at distances of $0.5-1 \mathrm{~km}$. They occasionally returned to their nesting sites in upland tundra, and we saw them either on the flood-plain or on the upland. By the end of July, ptarmigan were even more often seen in the willow thickets and rarely seen in their territories. Then they finally left their nesting sites altogether and stayed in flocks.

\section{Discussion}

Thus, the flocks of nonnesting ptarmigan in summertime can have a different origins and different structures. Our data confirm the results of Ryabitsev (1989) that the core of these flocks is comprised of unmated males, incapable of pairing, and therefore abandoning 
their territories. Another powerful factor influencing flock formation is predation pressure; for example, that of Snowy Owls upon adult ptarmigan which can cause almost all birds to associate in flocks excepting those just hatching and brooding females. On the one hand, the aggregating behavior is disadvantageous, as it increases competition for resources, but on the other, aggregated birds can more calmly feed without constantly having to look around. Therefore, the increased tendency of ptarmigan to flock in conditions of high predator pressure is quite explicable. But it is curious that, even in the absence of such pressure, many birds not occupied with reproduction (for example, due to depredation of nests) can form flocks, especially those of such high numbers. It is therefore remarkable that in the more southern areas of the Yamal, ptarmigan that have lost clutches (and even their partners) continue to remain at or near their breeding sites until autumn (Ryabitsev 1987, 1989).

Anomalous weather during the nesting period can also be a factor in the formation of summer flocks. In years in which the spring is cold and long, a considerable proportion of ptarmigan do not nest at all. Such cases in the north of Yamal were not observed in our studies, but have been noted, for example, by Pavlov (1974) in Taimyr. Only at superfluous density do summer flocks consist of the true population reserve of excluded birds ready to reproduce. Such flocks appear not only after birds are distributed on territories, but rather all spring long, such that spring migratory aggregation behavior simply continues into the summer (Ryabitsev 1993).

It is known that Willow Ptarmigan spend most of the annual cycle in flocks, breaking into pairs only during the period of reproduction. However, during nesting time, it is rare for numerous flocks to form. Ryabitsev (1993), during 20 years of work in the southern and central Yamal, witnessed such a phenomenon only twice. It is possible to assume that for Willow Ptarmigan in the Northern Yamal, already at the northern limit of the species range, the high tendency, in comparison with more southern areas, to unite in flocks in response to any obstacle to normal reproduction is characteristic. The long winter and very short summer force ptarmigan of this region to spend an unusually large part of their lives in flocks and to lead a territorial life for only the very short period of reproduction. In such conditions, the degree of mutual aggression characteristic of territoriality can be lowered. If so, even small obstacles to reproduction may be sufficient to return to a life in flocks.

\section{Literature Cited}

Bergerud, A. T., D. H. Mossop, And S. MyrBERGET. 1985. A critique of the mechanics of annual changes in ptarmigan numbers. Canadian Journal of Zoology 63:22402248.

Bergerud, A. T., S. S. Peters, ANd R. MCGRATH. 1963. Determining sex and age of Willow Ptarmigan in Newfoundland. Journal of Wildlife Management 27:700711.

HANNON, S. J. 1983. Spacing and breeding density of Willow Ptarmigan in response to an experimental alteration of sex ratio. Journal of Animal Ecology 52:807-820.

HANNON, S. J. 1984. Factors limiting polygyny in the Willow Ptarmigan. Animal Behavior 32:153-161.

HANNON, S. J., AND T. W. BARRY. 1986. Demography, breeding biology and predation of Willow Ptarmigan at Anderson River Delta, Northwest Territories. Arctic 39:300-303.

Hannon, S. J., AND J. Rowland. 1984. Morphology and territory acquisition in Willow Ptarmigan. Canadian Journal of Zoology 65:1502-1506.

HöHN, E. O. 1967. The relevance of J. Christian's theory of a density-dependent endocrine mechanism to the problem of population in birds. Ibis 109:445-446.

Mikheev, A. V. 1948. Belaia kuropatka. [Willow Ptarmigan.] Moscow, Russia. 
Moss, R. 1972. Social organization of Willow Ptarmigan on their breeding grounds in interior Alaska. Condor 74:144-151.

ORIANS, G. H. 1969. On the evolution of mating systems in birds and mammals. American Naturalist 103:589-603.

ORIANS, G.H. 1969. On the evolution of mating systems in birds and mammals. American Naturalist 103. Reprinted in T. H Clutton-Brock and P. H. Harvey (Eds.). Reading in sociobiology:115-132. Freeman, San Francisco, USA.

Page, G. D., And F. Whitacre. 1975. Raptor predators on winter shorebirds. Condor 77:73-83.

PAtTerson, I. J. 1980. Territorial behaviour and the limitation of population density. Ardea 68:53-62.

PAvlov, B. M. 1974. Belaia i tundrianaia kuropatki Taimira. [Willow and Rock Ptarmigan in the Taimir Peninsula.] Ph.D. Thesis. Moscow, Russia.

Piminov, V. N. 1985. Chislennost' i promysel beloi' kuropatki v Yamalo-Nenetskom avtonomnom okruge [Abundance and hunting of Willow Ptarmigan in the Yamalo-Nenets Autonomous Area]. Pages 156-169 in Resources of Hunting and the Forecasts of its Use. Moscow, Russia.

PIMINOv, V. N. 1990. Osvoenie resursov beloi' kuropatki na severe Tyumenskoi' oblasti [Resource development of Willow Ptarmigan in the north of the Tyumen region]. Pages 85-87 in Animal Resources of Siberia. Game Birds and Beasts. Novosibirsk, Russia.

PotAPOv, R. L. 1985. Otryad Kuroobraznye (Galliformes). Chast' 2. Semyei'stvo teterevinye (Tetraonidae). [Order Galliformes Part 2. Family Tetraonidae. Volume 3 Part 1.] Fauna SSSR, Suppl. 133:1-637. Leningrad, Russia.

RYABITSEV, V. K. 1987. Relaying of eggs and bicyclic behavior of birds of Yamal. Soviet Journal of Ecology 2:66-68.
Ryabitsev, V. K. 1989. Origin of male flocks and population reserve in the Willow Ptarmigan. Soviet Journal of Ecology 19:166-168.

RyabitseV, V. K. 1993. Territorial'nye otnosheniya i dinamika naseleniya ptits $\mathrm{V}$ Subarktike. [Territorial interactions and population dynamics of birds in the subarctic region.] Yekaterinburg.

RyabitseV, V. K., AND V. V. TARAsov. 1994. Summary flocking of Willow Ptarmigan in conditions of increased pressure from predators. Soviet Journal of Ecology 25:1-70.

Stinson, C. H. 1980. Flocking and predator avoidance: models of flockings and observations on the spatial dispersion of foraging winter shorebirds (Charadrii). Oikos 34:35-43.

TARASOV, V. V. 1997. Reproductive Success of Willow Ptarmigan, Lagopus lagopus, in the Northern Yamal. Russian Journal of Ecology 28:265-268.

VERNER, J. 1964. Evolution of polygamy in the Long-billed Marsh Wren. Evolution 18:252-261.

VERNER, J., AND M. WILLSON. 1966. The influence of habitat on mating-systems of North American passerine birds. Ecology 34:135-172.

Voronin, R. N. 1978. Belaia kuropatka Bol'shezemel'skoi Tundry: Ekologiia, morfologiia, khoziaistvennoe ispol'zovanie. [Willow Ptarmigan in the Big Land tundra: ecology, morphology, and economic use.] Leningrad, Russia.

Voronin, R. N. 1979. Breeding of the Willow Grouse (Lagopus lagopus) in the Bol'shezemel'skaya Tundra. Ornitologiya:133-138.

WEEDEN, R. B. 1964. Spatial separation of sexes in Rock and Willow Ptarmigan in winter. Auk 81:534-541. 
- TARAsov - 